7. Case T-61/13: Research and Production Company "Melt Water" UAB contre Office de l'harmonisation dans le marché intérieur (marques, dessins et modèles) (OHMI), T 61/13, ECLI:EU:T:2014:265 (p. 28)

8. Case F-29/05: Jean-François Vivier v European Commission, F-29/05, ECLI:EU:F:2010:114 (p. 67-70)

9. Case F-107/05: Gergely Toth v European Commission, F-107/05, ECLI: EU:F:2010:118 (p. 71-74)

10. Case C-394/12: Shamso Abdullahi v Bundesasylamt, C-394/12, ECLI:EU: C:2013:813 ( p. 51, 62

11. Case C-583/11: P Inuit Tapiriit Kanatami e.a. v European Parliament, Council of the European Union, C-583/11 P, ECLI:EU:C:2013:625 (p. 50)

12. Case F-81/09: Luigi Marcuccio v European Commission, F-81/09, ECLI:EU:F:2011:13 (p.55)

13. Case T-124/14: Republic of Finland v European Commission, T-124/14, ECLI:EU:T:2015:955 (p.24)

14. Case T-62/10 P: Brigitte Zangerl-Posselt v European Commission, T-62/10 P, ECLI:EU:T:2011:463 (p. 41, 43)

15. Case C-420/1: Maksu- ja Tolliamet v Heavyinstall OÜ,C-420/19, ECLI:EU:C:2021:33 (cf. point 27)

DOI https://doi.org/10.30525/978-9934-26-116-9-47

\section{ШЛЯХИ ВДОСКОНАЛЕННЯ АДМІНІСТРАТИВНО- ПРАВОВОГО ЗАБЕЗПЕЧЕННЯ ЗАПРОВАДЖЕННЯ МІЖНАРОДНИХ СТАНДАРТІВ У СФЕРІ ЗАХИСТУ ПРАВ ЛЮДИНИ В УМОВАХ СВРОПЕЙСЬКОЇ ІНТЕГРАЦІЇ УКРАЇНИ}

Криворучко Л. С.

доктор юридичних наук, адвокат

м. Київ, Україна

Шлях України до європейської спільноти передбачає впровадження нормативно-правового забезпечення та захист затверджених прав людини на основі принципів сучасного демократичного міжнародного права, створення правової, соціальної та демократичної країни відповідно до міжнародних стандартів країни, яка посяде гідне місце у світовому співтоваристві. Зазначені стандарти існують на загальноєвропейському рівні, подолали тернистий шлях становлення 
і будувалися на основі принципів сучасного демократичного суспільства, норм міжнародного права. Впровадження демократичних стандартів у національне законодавство - це не вимога, а потреба часу нашої країни.

Входження України до європейського правового простору визначається внутрішніми нормативними актами України, які є обов'язковою умовою інтеграції нашої країни до Свропейського Союзу та інших європейських структур. Ратифікація Україною основних міжнародних правових актів та договорів уже вказує про входження нашої країни до європейського правового простору та гарантує подальші кроки у цьому напрямку. Однією з головних тенденцій розвитку державності у світі $\epsilon$ використання найкращих досягнень політико-правової думки, до них належать такі загальнолюдські цінності, як демократія, права та свободи людини, гуманний і справедливий правопорядок [1]. Кожна держава не може розвиватися осторонь від інших країн світу, відносини між різними країнами мають економічний, політичний і культурний характер, і тому в результаті цих взаємовідносин відбуваються взаємне збагачення та розвиток. Європейський досвід побудови держави на основі демократичних цінностей $\epsilon$ запорукою демократичного розвитку і України.

Сьогодні в Україні існує досить узгоджена позиція, що інтеграція до Свропейського Союзу сприятиме розвитку економіки країни. Не викликає сумнівів позитивна роль інтеграційних процесів і у сфері забезпечення прав людини в Україні. Але успіх частково залежить від українського уряду, який повинен ефективно та продуктивно працювати 3 представниками Свропейського Союзу і здебільшого якісно координувати діяльність між міністерствами й агентствами держави [2].

Стратегія інтеграції України до Європейського Союзу грунтується на таких засадах:

- на положеннях Конституції України, що встановлюе спрямування зовнішньополітичної діяльності України на забезпечення іiі національних інтересів і безпеки шляхом підтримки мирного і взаємовигідного співробітництва 3 членами міжнародного співтовариства за загальновизнаними принципами і нормами міжнародного права;

- схвалених Верховною Радою України провідних напрямах зовнішньої політики України та Концепції національної безпеки України;

- Угоді про партнерство та співробітництво між Україною та Свропейським Співтовариством та його державами-членами від 1994 р. та інших договорах, укладених між Україною та Європейським Союзом, у яких визначаються механізми взаємодії між ними [3]. 
Етапами правової адаптації із захисту прав людини є такі: імплементація угод про партнерство та співробітництво, укладання галузевих угод, приведення чинного національного законодавства України у відповідність до міжнародних стандартів $Є С$, створення механізму приведення проектів нормативно-правових актів законодавства України у відповідність до норм ЄС. Ухвалені угоди надають особливий статус європейським правовим актам, які мають обов'язковий характер для впровадження у національне законодавство. Конституція України проголосила нашу країну правовою і соціальною державою, відповідно до чого на вищому рівні було затверджено певну модель стану держави.

Європейські інтеграційні процеси потребують комплексного вдосконалення нормативно-правового забезпечення захисту прав людини в Україні. Це вдосконалення має торкнутися всіх сфер діяльності нашої країни. Умовно основні напрямки вдосконалення нормативно-правового забезпечення захисту прав людини в Україні в межах європейської інтеграції та залежно від сфер діяльності можна поділити на такі:

- оптимізація діяльності державних органів влади та загальнодержавного управління;

- збільшення повноважень місцевих органів влади, децентралізація влади;

- інтенсифікація розвитку соціальної інфраструктури в регіонах;

- забезпечення прав людини й осіб, які мають обмежену здатність захищати свої права;

- широка і всеосяжна інформатизація суспільства.

Питання оптимізації діяльності державних органів влади та загальнодержавного управління в Україні є дуже важливим і має багато проблемних зауважень з боку Свропейського Союзу. До основних проблем діяльності державних органів влади та загальнодержавного управління в Україні можна віднести такі: розмежування діяльності та зменшення дублювання між різними гілками влади; розроблення механізмів, що унеможливлюватимуть порушення прав людини; впровадження надання адміністративних послуг; оптимізація структури державного апарату, його функцій, зниження фінансових і матеріальних витрат на його утримання; зменшення кількості чиновницько-бюрократичних ланок для сприяння якіснішому наданню адміністративних та управлінських послуг; підвищення іміджу та рівня довіри населення до органів влади; ефективний розподіл фінансових ресурсів на місцях; постійний конструктивний діалог між державними органами влади та населенням і громадськими організаціями; організація ефективного контролю за діяльністю адміністративної системи; ефективна 190 
підтримка діяльності державних і неурядових органів, що займаються забезпеченням прав людини, їх інтеграція в загальнонаціональний і світовий політичний та економічний простір; організація ефективного контролю за виконанням законів та адміністративних рішень; взаємодія і співробітництво 3 державними органами країн світу і міжнародними неурядовими організаціями.

Децентралізація влади та збільшення повноважень місцевих органів влади 3 урахуванням особливих вимог та уподобань громадян певних регіонів здатні підвищити значимість адміністративних рішень на місцях.

До головних проблем децентралізації влади та збільшення повноважень місцевих органів влади в Україні можна віднести муніципальне адміністративне управління, перерозподіл можливості користуватися місцевим та загальнодержавним бюджетом, розширення регіональних програм і збільшення їх кількості, ефективна підтримка на регіональному рівні діяльності державних та неурядових органів, що займаються забезпеченням прав людини, роль неурядових організацій у підвищенні ефективності діяльності органів місцевого самоврядування, державний та неурядовий контроль за діяльністю місцевих органів влади, можливість співробітництва на регіональному рівні 3 державними органами країн світу і міжнародними неурядовими організаціями.

Розвиток соціальної інфраструктури в регіонах та оптимізація іiі діяльності $\epsilon$ показником покращення стану забезпечення прав людини, критерієм покращення ставлення населення до адміністративної системи і держави в цілому, тому є дієвим способом подальшого розвитку демократичної держави. Соціальна інфраструктура забезпечує виконання майже всіх прав людини. До неї належать відносяться: житло та його будівництво, об'єкти соціально-культурного призначення, вся сфера житлово-комунального господарства, установи системи охорони здоров'я, освіти, дошкільного виховання; підприємства та організації, пов'язані з відпочинком і дозвіллям; роздрібна торгівля, громадське харчування, сфера послуг, спортивно-оздоровчі установи; пасажирський транспорт і зв'язок, обслуговування населення; система установ, що надають послуги правового та фінансово-кредитного характеру (юридичні консультації, нотаріальні контори, ощадні каси, банки) та ін. До головних проблем розвитку соціальної інфраструктури в Україні, які потребують вирішення, можна віднести доступність установ та організацій соціальної інфраструктури для населення, оптимізація якісних та кількісних показників соціальної інфраструктури в регіонах, преференції соціальної інфраструктури перед приватними економічними та фінансовими інтересами, об'єднання 
адміністративних послуг державних i місцевих органів влади, планування інфраструктури з урахуванням міжнародного досвіду.

Забезпечення прав людини для осіб, які мають обмежену здатність захисту своїх прав, є загальним показником ставлення до системи забезпечення прав людини в країні. Ставлення до прав людини в державі перевіряється за станом справ щодо забезпечення прав і свобод осіб, які мають обмежену здатність захищати свої права. Діти, інваліди, засуджені та затримані, постраждалі від злочинів та надзвичайних ситуацій, мігранти та біженці повинні мати додаткові гарантії щодо забезпечення прав людини. До головних проблем забезпечення прав людини для осіб, які мають обмежену здатність захищати свої права, в Україні можна віднести такі: впровадження міжнародного досвіду забезпечення прав людини для осіб, які мають обмежену здатність захищати свої права, вдосконалення адміністративної системи України з урахуванням вимог осіб, які мають обмежену здатність захищати свої права, впровадження ювенальної юстиції, роль неурядових організацій у забезпечення прав людини для осіб, які мають обмежену здатність захищати свої права, роль місцевих органів влади у забезпеченні прав людини для осіб, які мають обмежену здатність захищати свої права, місце соціальних фондів у забезпеченні прав людини для осіб, які мають обмежену здатність захищати свої права.

Ураховуючи вище сказане можна стверджувати, що стратегія інтеграційного курсу України до Європейського Союзу має позитивне значення, забезпечить доступ до міжнародних стандартів для України i ïx гарантії у політичному, інформаційному, економічному і правовому просторі, що дозволить значно підвищити захищеність прав людини в країні та вдосконалити стан нормативно правового забезпечення системи захисту прав людини в Україні.

Забезпечення захисту прав людини грунтується та розвивається на основних положеннях адміністративного, конституційного, міжнародного та цивільного права. Ці галузі права органічно поєднуються та доповнюють одна одну в сфері забезпечення прав людини, що має вагоме значення для інтеграційних процесів. Сучасний стан розвитку демократичного суспільства потребує інтегрованого та диференційованого підходу.

Питання дослідження адміністративно-правових засад запровадження міжнародних стандартів у сфері забезпечення захисту прав людини ретельно висвітлено в монографічному дослідженні [4]. Безсумнівно, сьогодні європейська інтеграція України є ефективним засобом удосконалення нормативно-правового забезпечення захисту прав людини в Україні, що, в свою чергу, сприяє становленню та 192 
зміненню громадянського суспільства в нашій державі та прискорить формування в країні системи правового забезпечення захисту прав людини.

Адаптація українського законодавства до європейського законодавства $\epsilon$ найважливішим загальнонаціональним завданням у процесі здійснення правової реформи в Україні, що забезпечить оптимальне функціонування гілок державної влади, надасть змогу забезпечити на рівні міжнародних стандартів додержання конституційних прав і свобод громадян України, дозволить значно прискорити проведення економічних реформ і забезпечить Україні гідне місце у світовій економічній системі.

\section{Література:}

1. Журнал Верховної Ради України // [Електронний ресурс]. Режим доступу: http://www.viche.info/journal/2149.

2. Мейх'ю А. Україна і європейська інтеграція: успіх також залежить від якісної координації // Дзеркало тижня. № 11. 2008. [Електронний ресурc]. - Режим доступу : http://dt.ua/POLITICS/ ukrayina_i_evropeyska_integratsiya_uspih_takozh_zalezhit_vid_yakis noyi_koordinatsiyi-53224.html.

3. Про затвердження Стратегії інтеграції України до Свропейського Союзу: указ Президента України від 11.06 .1998 р. № 615/98 (станом на 09.10 .12 р.) // [Електронний ресурс]. - Режим доступу : http://zakon3.rada.gov.ua/laws/show/615/98.

4. Криворучко Л.С. Адміністративно-правові засади запровадження міжнародних стандартів у сфері забезпечення захисту прав людини: монографія. Харків : Майдан, 2020. 396 с. 